\title{
People, Birds, Canoes, and Seafaring in the Pacific Islands \\ Richard Feinberg
}

DOI: 10.21104/CL.2020.3.03

\begin{abstract}
Birds around the Pacific are identified with human activities, and often with people themselves. This article explores the pervasive use of birds and avian imagery by Pacific islanders in legend, song, canoe construction, and navigation. It considers a preoccupation with birds in diverse spheres of island life, but with special attention to maritime activities.
\end{abstract}

Key words

Oceania, birds, symbolism, seafaring

\section{Acknowledgment}

An earlier version of this paper was presented at a panel titled "Beyond the Human in the Pacific" at the 10th Conference of the European Society for Oceanists, held in Brussels, Belgium on 24-27 June 2015. Data on which this work is based were collected through multiple visits to the Solomon Islands and Papua New Guinea, between 1972 and 2013. Those expeditions were supported by the US National Institute of Mental Health, the US National Science Foundation, the UN Secretariat for the Convention of Biodiversity, and the Kent State University Research Council. The manuscript has benefitted as a result of critical comments from Česky lid editor Dr. Jana Nosková and three anonymous reviewers. Above all, I am indebted to my many interlocutors on Anuta, Nukumanu, and Taumako islands in the southwestern Pacific.

\section{Contact}

Richard Feinberg, Ph.D., Kent State University (Professor Emeritus: Department of Anthropology), PO Box 5190, Kent, OH 44242, USA; e-mail: katoakitematangi@gmail.com.

Jak citovat / How to cite

Feinberg, Richard. (2020). People, Birds, Canoes, and Seafaring in the Pacific Islands. Český lid 107, 335-350. doi:http://dx.doi.org/10.21104/ CL.2020.3.03 


\section{Introduction}

Once upon a time, a group of men on the small island of Taumako went into the bush to cut materials for a canoe (see figures 1 and 2). They were joined by a precocious young boy named Lata. As they went along, they encountered a pigeon who had become ensnared in the branches of a tree. The bird asked each of the passers-by to help free him, but one by one the men declared themselves too busy. Lata, in contrast with the grown men, stopped to help; in return, the pigeon told him how to build the first truly seaworthy voyaging canoe, known as te puke. Lata is a celebrated culture hero throughout Polynesia. ${ }^{1}$ And, even today, every Taumako voyaging canoe has a carving of a pigeon lashed to each end of the hull (see figures 3 and 4). People of the Vaeakau-Taumako region relied on such canoes for

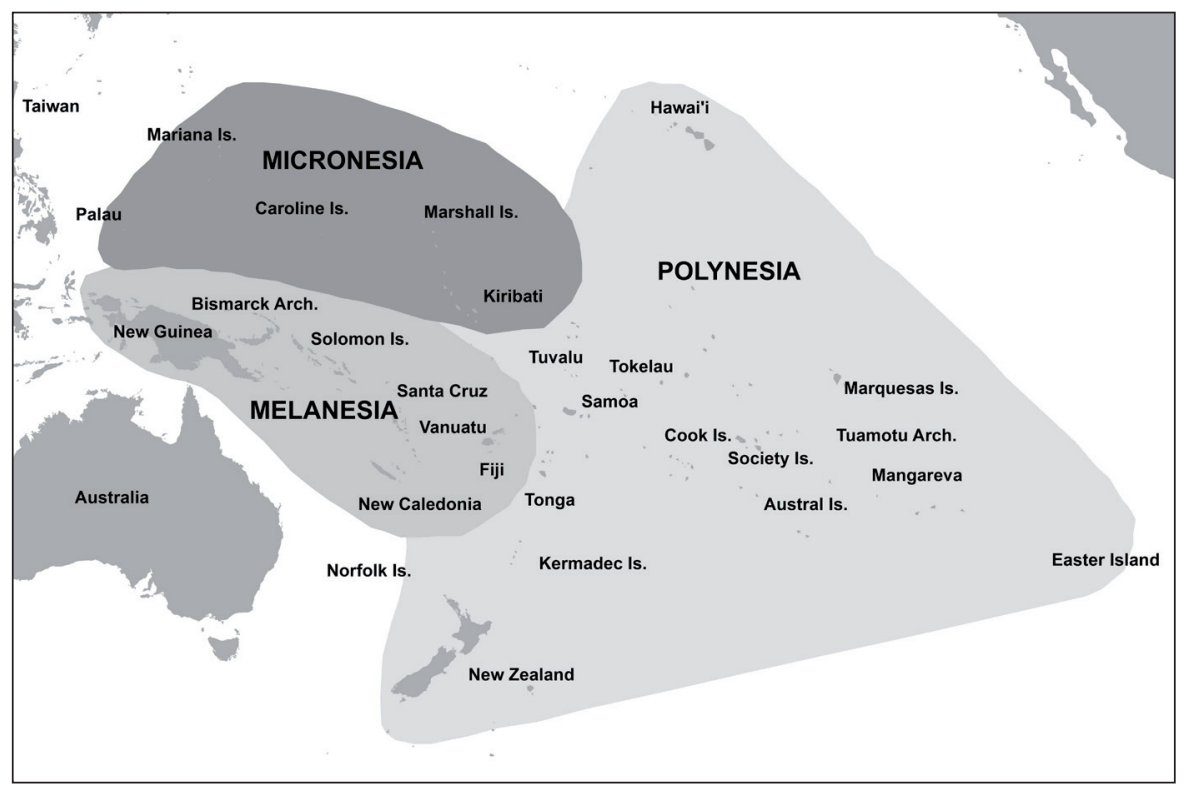

Figure 1 Map depicting major culture areas of Oceania. From R. Feinberg and R. Scaglion (2012: 2). Reprinted with permission.

1 Lata, in other parts of Polynesia, is sometimes known as Rata, Laka, or La'a. Joseph Grim Feinberg (n.d.) has compiled a bibliography of over a hundred versions of the Lata story and works that help to make sense of the tales. Sound recordings of several renditions as related to me by Taumako story tellers are available in the Hamilton Library's Pacific Collection at the University of Hawai' $i$. A readily accessible retelling on the Internet is available via Outer Voices (n.d.). 


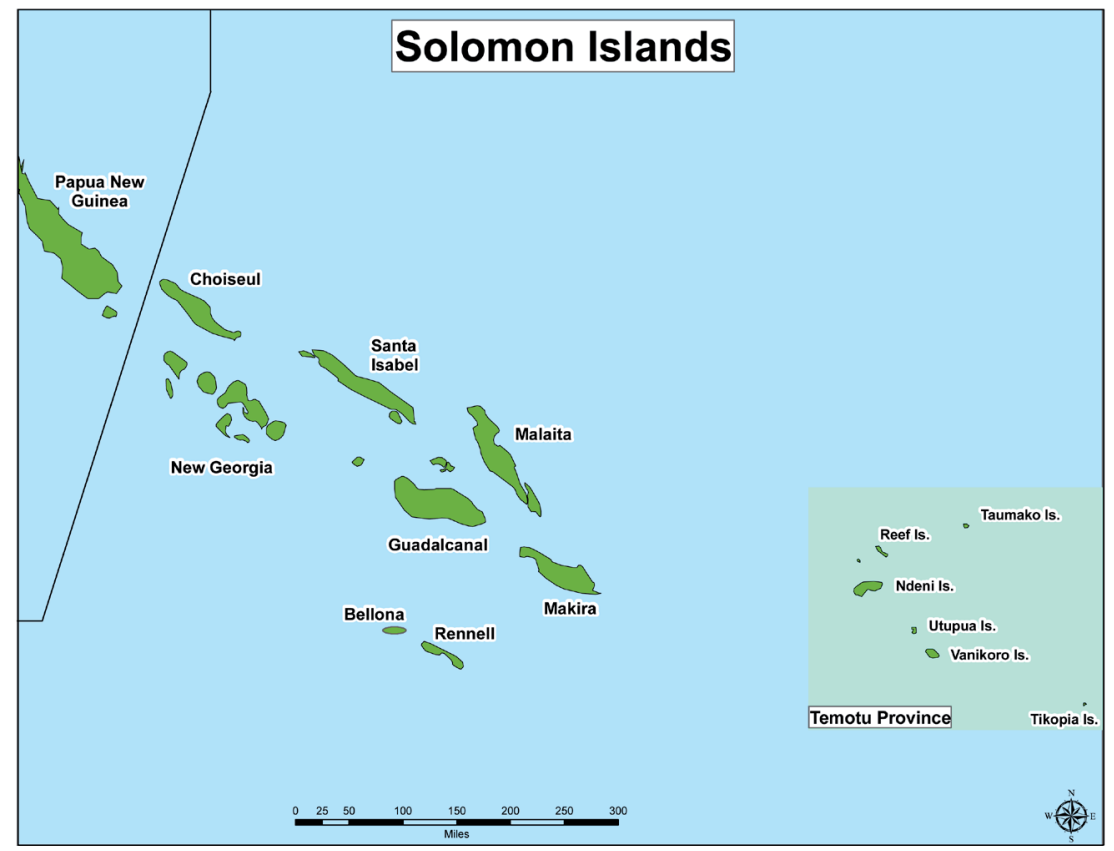

Figure 2 Map of Solomon Islands showing position of Taumako. From Feinberg and Genz (2012: 339). Reprinted with permission.

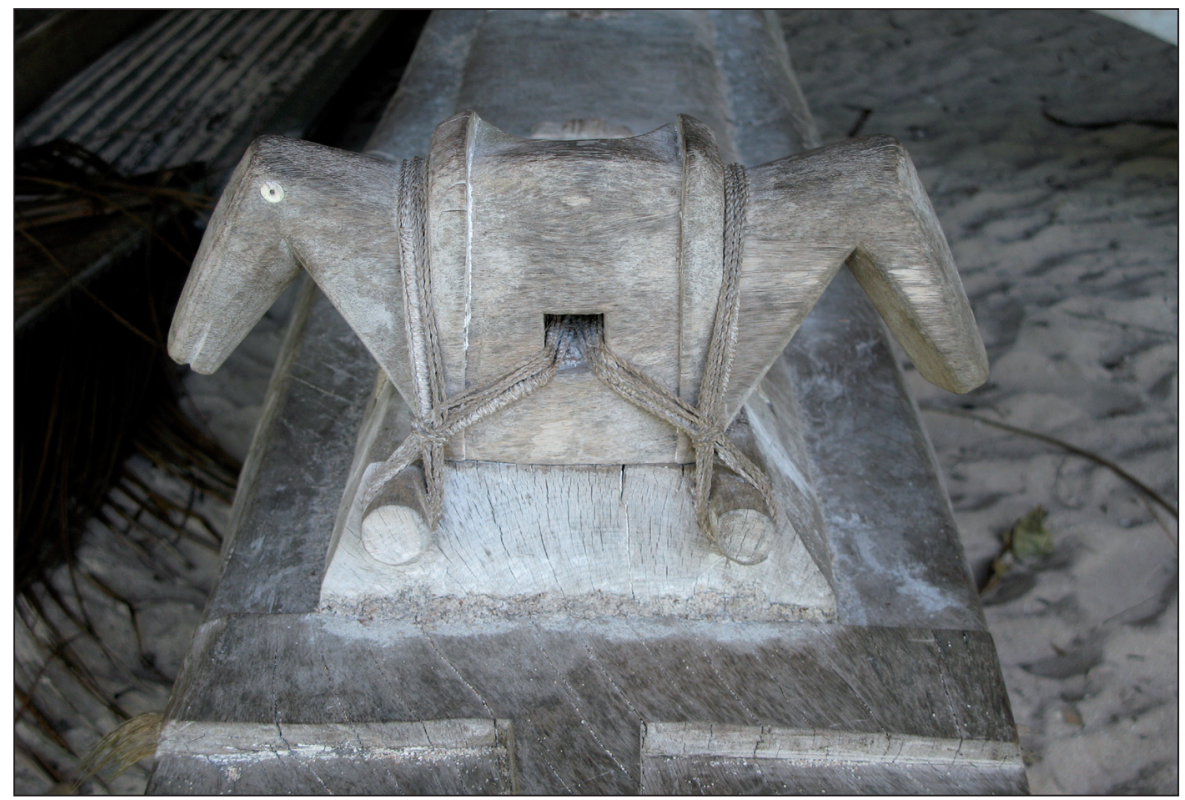

Figure 3 Pigeon ornament on bow of Taumako voyaging canoe. Photograph by R. Feinberg. 


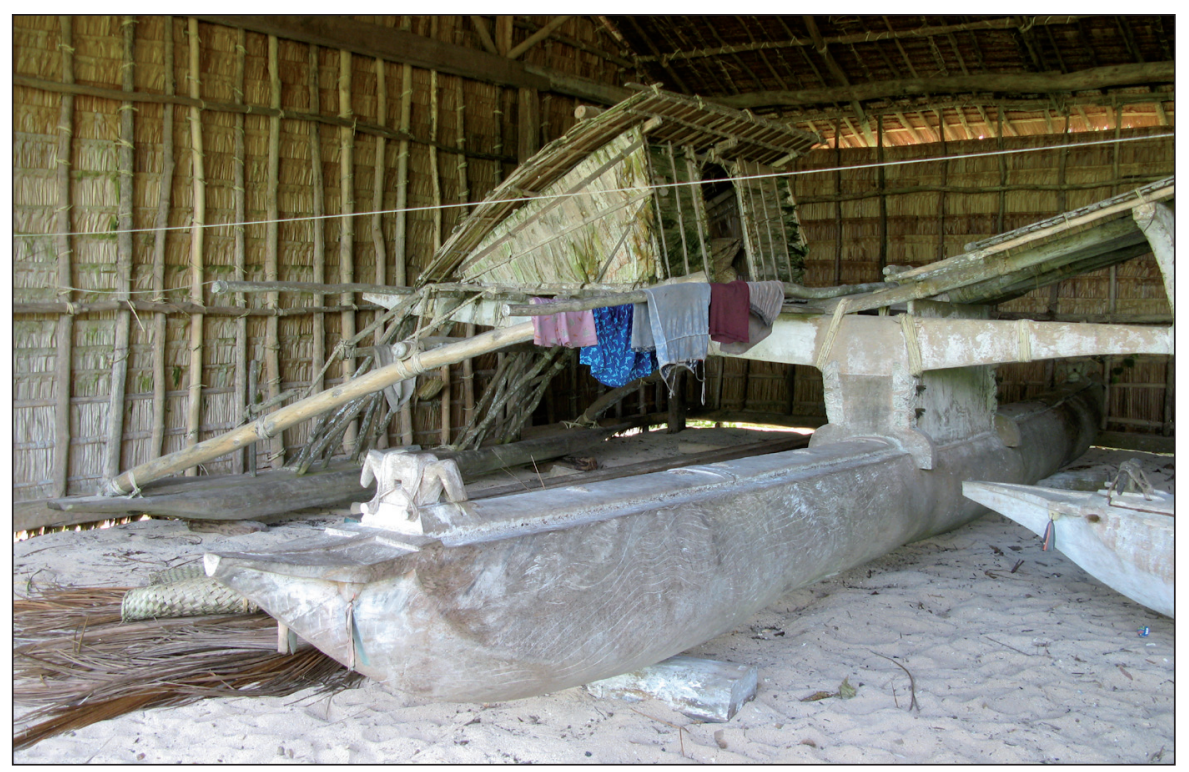

Figure 4 Taumako voyaging canoe, showing location of pigeon ornament.

Photograph by R. Feinberg.

countless generations as they traded for the famed Santa Cruz 'red feather money' (Davenport 1962; 1964). ${ }^{2}$

On the western edge of the Pacific, in the highlands of what is now Indonesian New Guinea, a group of anthropologists and filmmakers created a now-classic documentary on Dani warfare. At the end of 'Dead Birds', the narrator observes that birds, like people, share mortality, the difference being that humans, unlike birds, are conscious of their fleeting time on earth (Gardner 1963; 2008; Heider 1979). Meanwhile, thousands of miles to the northeast, prominent Hawaiian chiefs adorned themselves with feather capes. And, on Rapanui in the far eastern corner of the Polynesian Triangle, the tangata manu or 'birdman' cult became the island's

2 For generations, the Taumako were involved in an elaborate trade network that permeated the Santa Cruz region of the Southeastern Solomon Islands. They made large, sophisticated outrigger canoes and sold them to traders in the Polynesian Outer Reef Islands (known locally as Vaeakau). Vaeakau seafarers then sailed them to the large Melanesian Islands of Vanikoro and Utupua, where they exchanged such products as fish and turtles for long scrolls of so-called red feather money or muahau. The Vaeakau islanders, in turn, used the feather money to pay the Taumako craftsmen for the canoes. On Taumako, itself, the muahau was used for bridewealth payments and a variety of ceremonial exchanges. 
premier spiritual focus, as the winner of an annual competition was transformed into a human incarnation of Makemake, the creator god. ${ }^{3}$

As suggested by this brief review, birds around the Pacific are identified with human activities, and often with people themselves. This article explores the pervasive use of birds and avian imagery by Pacific islanders in legend, song, canoe construction, and navigation. In the time since I presented these thoughts at a meeting of the European Society for Oceanists (Feinberg 2015), Raphael Richter-Gravier, a graduate student at the University of Otago in New Zealand, completed an exhaustive dissertation on birds in Polynesian myths and legends (Richter-Gravier 2019). My contribution pales in comparison with Richter-Gravier's detailed account. His focus, however, is squarely on birds' presence in Pacific Island oral narratives and their written progeny. Here I highlight a preoccupation with birds in diverse spheres of island life, but with special attention to seafaring and navigation. My purpose at this stage is not to propose a comprehensive theoretical framework, but to complement Richter-Gravier's work by taking note of a phenomenon whose widespread appearance calls for further analytical assessment.

\section{Birds and Navigation}

Oceanic seafarers commonly rely on actual birds for purposes of land finding (see, e.g., Gladwin 1970; Lewis 1972; Feinberg 1988; 1995). This is critical when one is far enough from the destination island that it is not yet visible but close enough that there is a real risk of sailing past and getting lost at sea. Depending on the weather and the island's altitude, that might be anywhere ten to more than fifty kilometres. Under such conditions, navigators often look for bird species that nest on land at night and fly to sea to fish during the day. A navigator who sees such birds flying in a straight line at dawn assumes that they are coming from their nesting grounds and sails in the direction from which the birds have come. At dusk, the navigator assumes that they are returning home and follows in their figurative wake.

While on the open sea, too far from land to rely on the flight patterns of literal birds, islanders navigate by following wave patterns and the movements of stars. Yet even here, birds play a central - if metaphorical role. As Gladwin (1970) famously observed, on the Micronesian atoll of Polowat, the eastern sky is dominated by 'The Big Bird' - the constella-

3 For one classic account of Rapanui (also known as Easter Island), see Métraux 1940. A brief but useful summary appears in Goldman 1970. 
tion known to Western astronomers as Altair. ${ }^{4}$ The Bird is Polowat's most important navigational constellation, and it serves as the centrepiece of an intricate system of logic and empirical knowledge.

For Anuta, a Polynesian community in Temotu Province of the southeastern Solomon Islands, east is a still bigger bird. The most important constellation in Anuta's sky is known as Manu, a name that literally means 'Bird' (see figure 5). In the Anutan case, the bird's body (Te Tino a Manu) is the brightest star in the night sky, Sirius. From one wingtip to the other, the constellation stretches across perhaps a quarter of the sky: from Canopus (Te Kapakau Tonga, the 'East Wing' or 'Southeast Wing') to Procyon (Te Kapakau Pakatokerau or 'North Wing'). A cluster of four relatively small stars is located near Manu's body but set off in the direction of the Southeast Wing. This is Te Kaokao o Manu 'Manu's Armpit' or 'Wingpit', and it passes almost directly over Tikopia. Tikopia is Anuta's nearest populated neighbour, approximately 125 kilometres to the southwest. The two islands are similar in language and culture, and they have been in communication for

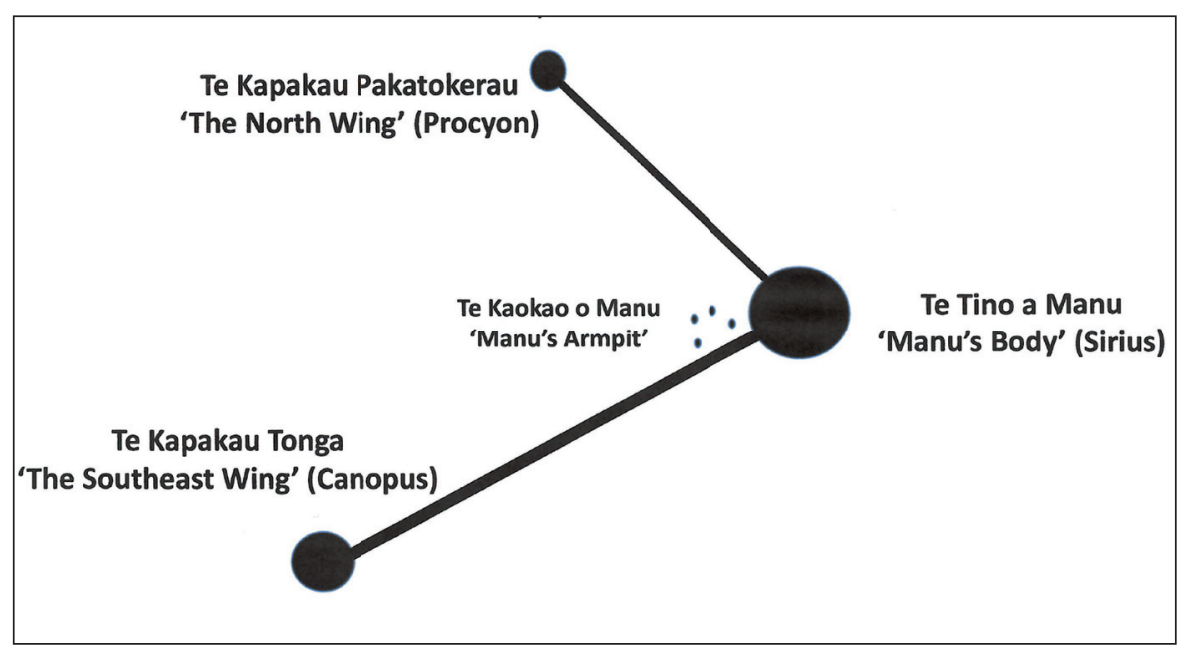

Figure 5 Diagram of the Anutan constellation, Manu 'Bird'. Drawn by R. Feinberg.

4 At the time of Gladwin's publication, the atoll's name was typically spelled Puluwat. Since gaining independence, the Federated States of Micronesia a former United States Trust Territory - has changed the official spelling of several islands to approximate more closely local pronunciation. Holton et al. (2015) argue that Gladwin was mistaken in identifying Altair as Polowat's 'Big Bird'; the correct constellation, they contend, is Sirius (Mannap). That recalculation, if accurate, aligns Polowat more closely with the Polynesian islands discussed below. 
centuries. Manu's Wingpit, thus, has been a critical signpost guiding generations of Anutan navigators to one of their most common destinations. ${ }^{5}$

On Nukumanu (Feinberg 1995) and Taumako (Feinberg - Genz 2012), Manu is again a vital navigational constellation, and again its body is Sirius. Nukumanu is an atoll in the Bougainville Autonomous Region of Papua New Guinea; Taumako is a small high island in the Solomons' Temotu Province, about 300 kilometres northwest of Anuta. On Nukumanu, as on Anuta, Manu has two wings or arms; and, again, those are Canopus and Procyon (or, according to a few Nukumanu commentators, Canopus and Monocerus). Some Taumako islanders identify Manu as a man rather than a bird, making Canopus and Procyon arms rather than wings. However, the body, Sirius, is the same, and the word, manu, as through most of Polynesia, designates a bird in common speech.

'Manu' refers not only to mortal birds and to constellations; it designates a spiritual being that connects the two. Anutans tell the story of Motikitiki (the local variant of the pan-Polynesian trickster and culture hero, often known by his Hawaiian name of Maui; see, e.g., Luomala 1949). According to Anuta's tale (Feinberg 1998), Motikitiki - who hatched from an egg - followed his father into the heavens (Nga Rangi) and was assigned to ask for Manu's fire-stick. After Manu obligingly provided Motikitiki (and, thereby, all of humanity) with the secret of fire, the two of them got into a fight. Motikitiki broke Manu's wing, and Manu retreated into the sky, where he became the massive constellation. One wing (Procyon) is shorter than the other (Canopus) because Motikitiki broke it in their fight. Motikitiki and his two brothers eventually followed Manu into the sky, where they are known today as Aratoru 'Path of Three', the three stars that make up Orion's belt.

\section{The Hatching of a 'Bird Canoe'}

Anuta's standard single-outrigger ocean-going canoes with covered bow and stern are called vaka pai manu 'canoes after the design of birds'(see figure 6). The carved bow and stern coverings are said to resemble a bird's head and tail, respectively (see figures 7 and 8). The resemblance is rather abstract, but considerable detail is shown. It includes such anatomical features as a 'beak', 'crest', 'chin', 'ears', 'back',

5 Owing to generations of close contact as well as cultural and linguistic similarities, many Anutans have adopted Tikopian linguistic conventions. Therefore, as is true of several constellations, Anutans often refer to Te Kaokao o Manu by its Tikopian name, Te Opinga o Manu. 
and 'side'. ${ }^{6}$ A central ridge of triangular or pyramidal serrations runs along the upper surface of the bow and stern manu 'bird'. These are sometimes known as pakarakei 'decoration', pakataratara 'barb design', or nga $k a t e i$, a word for which I have no English gloss. Significantly, the design is also known as pakaatutangata 'as done in the abode of human beings' ${ }^{7} \mathrm{Al}-$ though I was able to obtain no indigenous exegesis, this name juxtaposes birds to human beings. Either the serrated ridge represents people as part of the bird ornament or it serves as a mediating symbol, connecting the 'birds' at the bow and stern with the central region of the canoe, where people sit while fishing, paddling, or sailing. 'Bird canoes' are large craft, sometimes measuring over ten meters in length and carrying as many as seven passengers on a journey of considerable distance. In contrast with Micronesian voyaging canoes as well as those found in most Polynesian outliers, the bow (mataavaka) and stern (taumuri) of vaka pai manu are distinct both terminologically and in design.

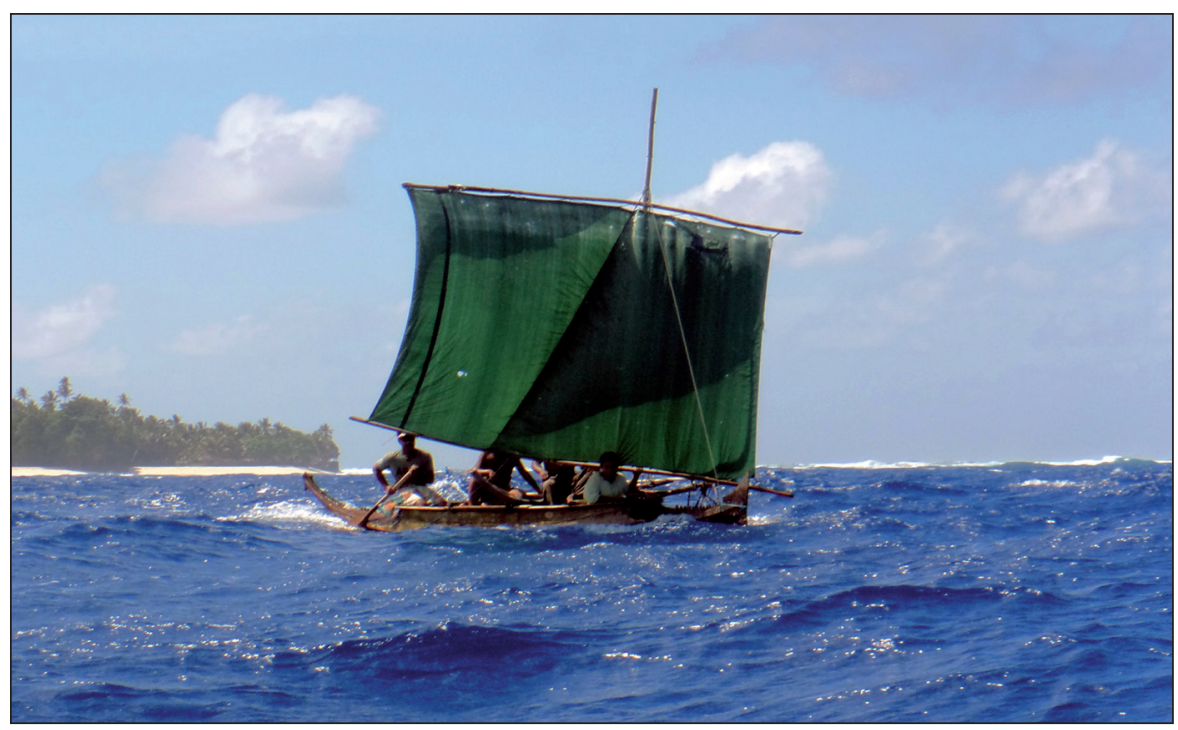

Figure 6 Anutan vaka pai manu 'bird canoe'. Photograph by R. Feinberg.

6 I am uncertain as to what Anutans have in mind when they refer to a bird's chin and ears; those, however, are the best English glosses I can offer, based on what the Anutan words designate when directed toward a person.

7 Atu in this context is the Anutan term for an archipelago or a region. Te Atu Runga, for example, means something like 'The Lands to the East', and Te Atu Piti is 'The Lands of Melanesia'. Paka is a causative prefix, and tangata means 'human' as opposed to atua 'spirit'. 


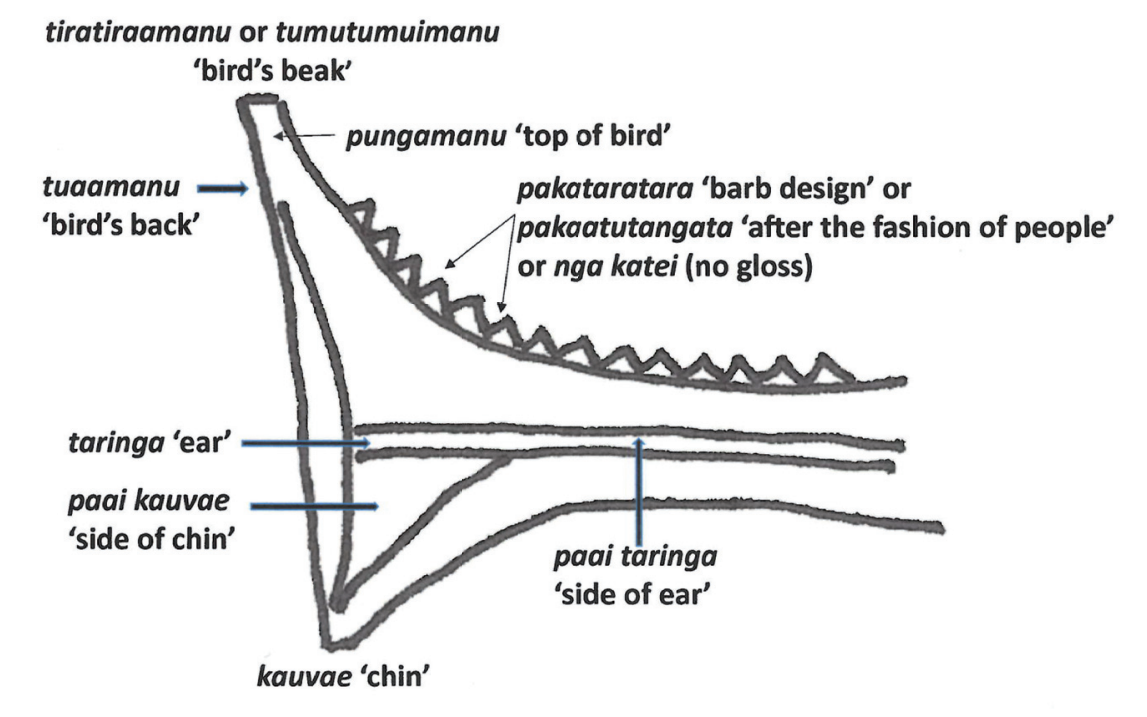

Figure 7 Diagram depicting bow manu of an Anutan 'bird canoe'. Drawn by R. Feinberg, based on illustration in Feinberg 1988: 50.

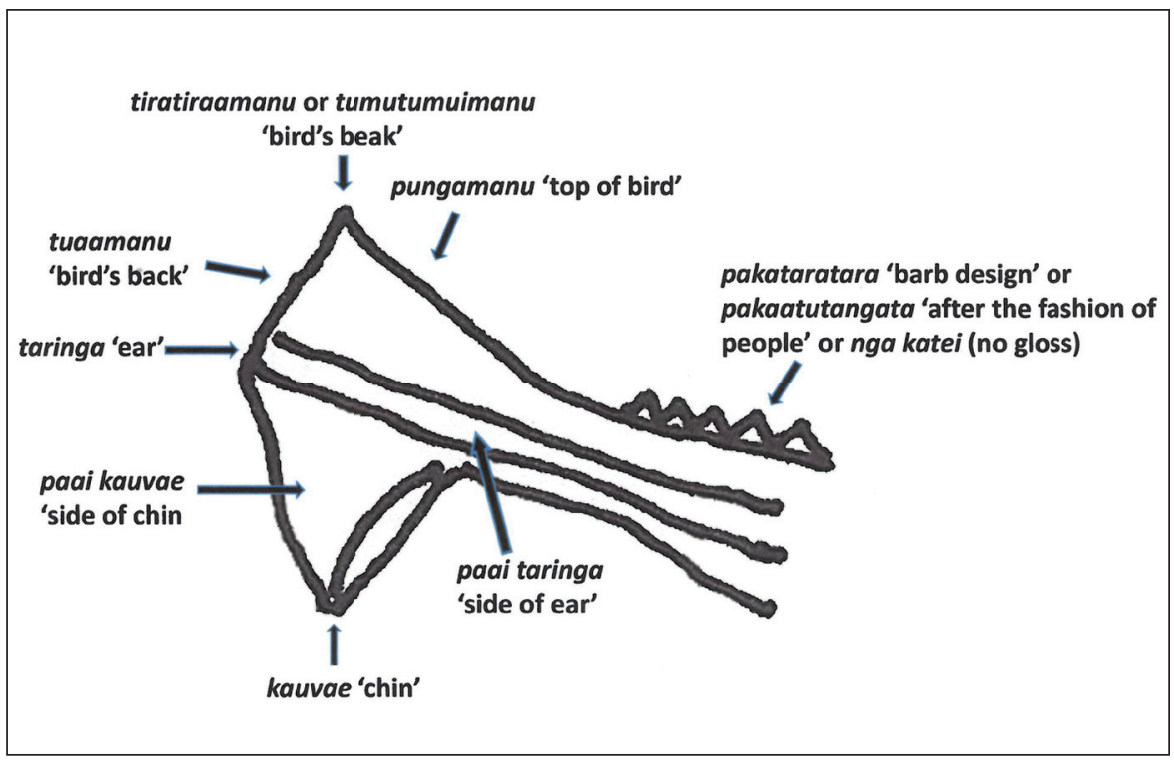

Figure 8 Diagram depicting stern manu of an Anutan 'bird canoe'. Drawn by R. Feinberg, based on illustration in Feinberg 1988: 51. 
In addition to vaka pai manu, Anutans construct small outrigger canoes without bow and stern covers and with identical ends. A few such craft, known as tozi, are found on Anuta; however, they rarely carry more than one or two paddlers and can only be used in the calmest weather. Anuta is a volcanic island, surrounded by a fringing reef and no lagoon. Surf constantly pounds on the reef and, under normal conditions, a canoe with low gunwales and no decking would quickly swamp when entering or exiting the island. Tovi, however, are quicker and easier to build than vaka pai manu, and the care put into construction of the more elaborate vessels is rarely lavished on the smaller ones. When Anutans emigrate to the central Solomons where they are dependent on wage work, time is precious, and protected water plentiful, tovi are often made in preference to the larger 'bird canoes'. Anuta's neighbour, Tikopia, being larger and enjoying easier access to the open sea, does not have to deal with surf to the same extent. Therefore, many Tikopian vessels are of the tovi type. As early as the $1980 \mathrm{~s}$, in the Tikopian colonies on Vanikoro, Makira, and in the Russell Islands, 'bird canoes' were practically non-existent. Today they have been virtually abandoned on Tikopia itself.

Anutans continue the bird motif for outriggerless dugout canoes, which are termed puai vaka 'egg canoes' and distinguished from vaka pai ama 'outrigger canoes'. Comparing them to eggs suggests that they are rudimentary and undeveloped. Such canoes are now in common use through most of the Solomons, but they are not made by Anutans, who identify them as Melanesian types and pay them little respect. ${ }^{8}$

\section{Of Birds and $\mathrm{Men}^{9}$}

Not only do Anutans (and Tikopians) liken canoes to birds, and not only is the sky for many Oceanic peoples dominated by The Bird, but voyagers are metaphorically depicted as birds in poetry and song. Thus, the composer of one Anutan dance song calls a member of an expedition landing on his island 'ko te manu o te moana' 'a seabird', and the composer of another depicted me as 'ko te manu mai Amerika' 'a bird from America'. In one erotic song, we hear: 'Ka eva te manu o te moana' 'The seabird will venture forth' - that is, a lover will go to his sweetheart, who is 'te noponga o te manutai' 'the dwelling place of the manutai (a kind of seabird)'. In another song, an Anutan who has travelled abroad on a European ship says,

8 In fact, outriggerless dugouts have also been adopted on many of the Polynesian islands of the Solomons. They are much easier and quicker to make than traditional voyaging canoes, and suitable trees are more abundant.

9 With apologies to John Steinbeck (1937). 
'Kau too ki te manu pakarere' 'I return like a flying bird'. One text quotes a father observing that his son, a 'muromuro tamaaroa' 'virgin young man' has adorned himself and gone (eva) to the ocean, which presumably represents his future sphere of (sexual) activity. And finally, the phrase 'te manu ku eva' 'the bird has ventured forth' takes on a sad significance in a Tikopian dirge recorded on Anuta, in which it refers to a youth's death. The seabird represents a being that lives on the ocean, coming ashore only to sleep. Its having no proper home evokes a sense of sadness. Furthermore, in keeping with the theme of voyaging and navigation, the bird represents a masculine identity, depicted as an instigator of activity, with freedom to move at will. ${ }^{10}$ Even its death is an active rather than a passive event. ${ }^{11}$

On Polowat, Anuta, Nukumanu, and elsewhere, the most important navigational constellation is 'Bird' or 'The Bird'. For Anuta, Nukumanu, and Taumako, Manu 'Bird' is centred on Sirius, the brightest star in the sky, and occupies a major portion of the heavens. Nukumanu song and story use the bird metaphor, as on Anuta, to depict voyagers as rootless wanderers. The Melanesian Kwara'ae depict voyagers as birds for the same reason (David Gegeo, personal communication). The ends of Carolinian canoes in what is now the Federated States of Micronesia are carved to resemble a frigate bird's tail (see figure 9), and models of the old Takū and Nukumanu sailing canoes (vaka fai lā and vaka hai lā, respectively) were built with ends intended to resemble a bird's beak. In the western Solomons' Marovo Lagoon, war canoes were decorated with humanlike images holding 'either a seabird (for navigational aid) or a human head (for success in headhunting) ...' (Hviding 1995: 100). In Papua New Guinea's Milne Bay Province, canoes are decorated with bird designs (Lepowsky 1995: 36; Damon 2017), and elaborate food taboos suggest an identification of human beings with birds (Montague 2001).

Frederick Damon (2017) documents the remarkable environmental knowledge of participants in the Milne Bay region's kula ring, made

10 The sea for Anutans is an almost-exclusively male domain. Many Polynesian communities have adopted a considerably less rigid gender-based division of labour. On Nukumanu and Taumako, for example, women often paddle, pole, sail, and fish from canoes. Anutan women may fish with nets on the reef flat. Fishing from a canoe in the open sea, beyond the surf line, however, is entirely a male activity, and long-distance canoe voyaging is almost completely so. The one inter-island voyage in which I participated (Feinberg 1988: chapter 7) involved a fleet of three canoes, each of which carried one woman whose job it was to tend the fire and prepare food for the crew.

11 Much of this analysis of Anutan poetic imagery grows out of conversations with Jacob Love, to whom I am much indebted. 
famous a century ago by Malinowski (1922). He moves from a focus on trees and their connection to vegetable cultivation in the Woodlark islands to canoe design and the complex interrelations throughout the region among a wide variety of plants and animals, including birds. A kuk 'rooster', positioned at the top of a Muyuw canoe's mast, provides a pulley for the halyard. The head of a bunibwan 'sea eagle', a bird that nests in trees and soars above the land- and seascape to locate resources and find the way to destination islands, is positioned at each end of the keel. A structure that helps hold the prow in place is likened to a heron. The image of another bird, perhaps a type of kingfisher, adorns the canoe's hull, and the bird itself serves as a harbinger of safe arrival. Frigate birds are sometimes used for landfinding, while bird images on a vessel's bow and stern may signal to people on shore the loss of a crew member.

Lastly, the Dani, as noted at the outset of this article, are renowned for their perceived analogy of birds to people. Although the Dani do not practice voyaging in the sense found among coastal dwellers of New Guinea and inhabitants of smaller islands, the bird metaphor is for them associated with warfare - a risky and challenging preoccupation that appears to occupy a comparable position in their social and symbolic systems.

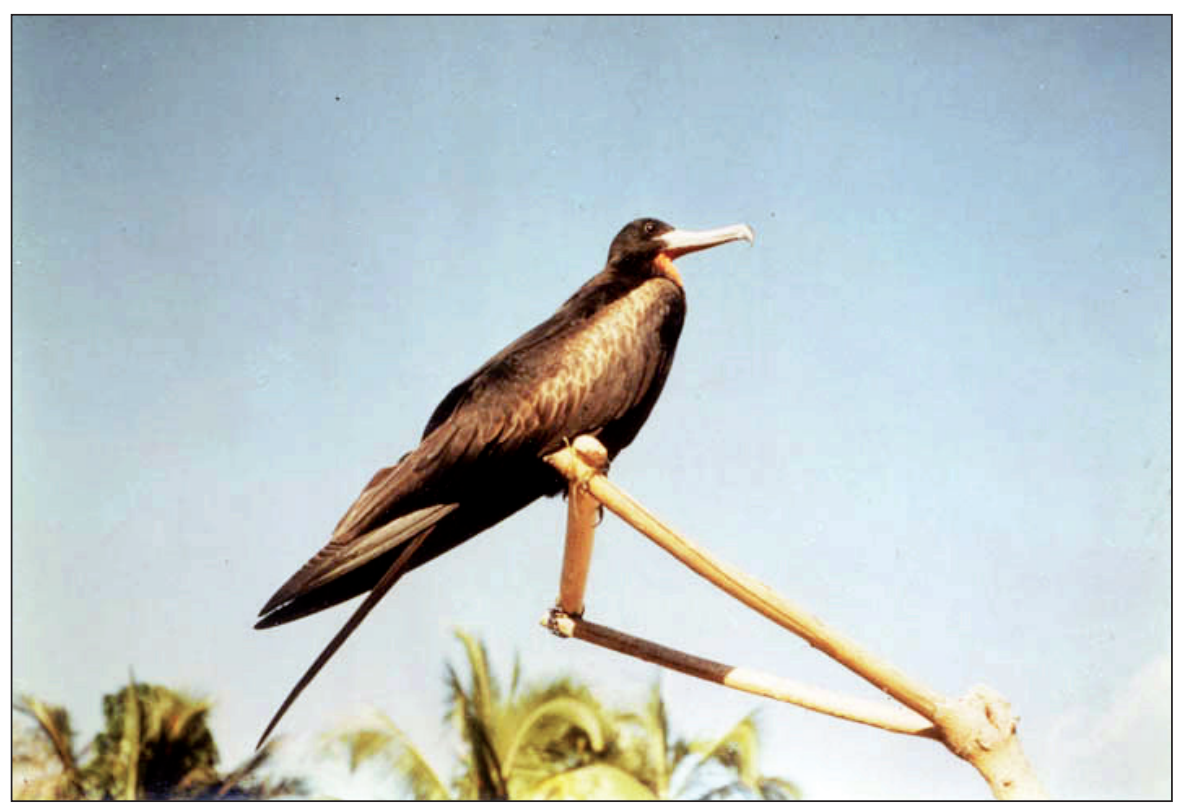

Figure 9 Pet frigate bird on Anuta Island. Photograph by R. Feinberg. 


\section{Conclusion}

The bird metaphor in many Pacific communities permeates those cultural domains involving ocean travel, navigation, and canoes. In poetry, song, legend, and myth, birds are identified with people, often depicting voyagers as somewhat pitiable wanderers - as beings that inspire what Polynesians call by some cognate of aloha 'sympathy', 'pity', or 'empathy'.12 The significance of birds is underscored through much of Oceania in canoe design as well as astronomical and navigational systems.

Birds, of course, are also important in cultures well beyond the Pacific. Among Austronesian speakers of Borneo, to take but one example, they connect the human with the spiritual world, and elaborate systems of 'bird augury' have been documented in considerable detail (Freeman 1960; Metcalf 1976). And as far afield as European and North American folk tales, folk songs, or even a popular children's television show, birds are often featured for their humanlike traits. In Oceania, however, they are given special prominence.

The latter point, perhaps, is unsurprising. As Richter-Gravier (2019) observes, Pacific islands host few varieties of non-marine fauna. Should people seek non-human analogues to add nuance and perspective to their understanding of the human condition (cf. Lévi-Strauss 1963a; 1963b; 1963c; 1966), the avian world is, therefore, an obvious place to look. More surprising, perhaps, is the relative paucity of studies of birds and their cultural significance in Oceania.

In this article I have not attempted an exhaustive survey and, clearly, the symbolic use of birds is inconstant as one moves from island to island. My objective, rather, has been to complement Richter-Gravier's encyclopaedic treatment; call attention to the exceptionally widespread connection between avian imagery, seafaring, and comparable activities around the Pacific; and shine a special light on the Polynesian outliers where I have carried out substantial field research. If I am correct, more systematic attention to this aspect of cosmology by ethnographers concerned with voyaging and ocean lore may offer valuable insight into what it means in Oceanic cultures to be human.

June 2020

12 Aloha is the well-known Hawaiian variant. Other examples include aroha (New Zealand Māori), alofa (Samoan), 'ofa (Tongan), and arofa (Tikopian). I have discussed the Anutan concept of aropa in several publications; for the most extended exegesis, see Feinberg 2011. 


\section{References}

Damon, Frederick H. 2017. Trees, Knots, and Outriggers: Environmental Knowledge in the Northeast Kula Ring. New York: Berghahn Books.

Davenport, William. 1962. Red-feather Money. Scientific American 206, 3: 94-104.

Davenport, William. 1964. Notes on Santa Cruz Voyaging. Fournal of the Polynesian Society 73: 134-142.

Feinberg, Joseph Grim. n.d. Bibliography of Lata Stories, compiled by Joe Grim Feinberg. Unpublished manuscript.

Feinberg, Richard. 1988. Polynesian Seafaring and Navigation: Ocean Travel in Anutan Culture and Society. Kent, Ohio: Kent State University Press.

Feinberg, Richard. 1995. Continuity and Change in Nukumanu Maritime Technology and Practice. In: Feinberg, Richard (ed.): Seafaring in Contemporary Oceania: Studies in Continuity and Change. DeKalb, IL: Northern Illinois University Press: 159-195.

Feinberg, Richard. 1998. Oral Traditions of Anuta: A Polynesian Outlier in the Solomon Islands. Oxford Studies in Anthropological Linguistics, Volume 15. New York and Oxford: Oxford University Press.

Feinberg, Richard. 2011. Do Anutans Empathize? Morality, Compassion, and Opacity of Other Minds. In: Hollan, Douglas W. - Throop, C. Jason (eds.): The Anthropology of Empathy: Experiencing the Lives of others in Pacific Societies. ASAO Studies in Pacific Anthropology, Volume 1.

New York and Oxford: Berghahn Press: 151-167.

Feinberg, Richard. 2015. People, Birds, and Navigation around the Pacific. Presentation to panel titled "Beyond the Human in the Pacific" at the 10th Conference of the European Society for Oceanists. Brussels, Belgium. June 24-27.

Feinberg, Richard - Genz, Joseph. 2012. Limitations of Language for Conveying Navigational Knowledge: Way-finding in the Southeastern Solomon Islands. American Anthropologist 114, 2: 336-350.

Feinberg, Richard - Scaglion, Richard. 2012. Introduction: The

Polynesian Outliers. In: Feinberg, Richard - Scaglion, Richard (eds.): Polynesian Outliers: The State of the Art. Ethnology Monographs, No. 21. Pittsburgh: University of Pittsburgh Press: 1-16.

Freeman, J. Derek. 1960. Iban Augury. In: Smythies, Bertram E. (ed.): The Birds of Borneo. Edinburgh, Scotland: Oliver and Boyd: 73-96.

Gardner, Robert. 1963. Dead Birds. Watertown, MA: Documentary

Educational Resources. 
Gardner, Robert. 2008. Making Dead Birds. Cambridge, MA: Peabody Museum Press.

Gladwin, Thomas. 1970. East is a Big Bird: Navigation and Logic on Puluwat Atoll. Cambridge, MA: Harvard University Press.

Goldman, Irving. 1970. Ancient Polynesian Society. Chicago and London: University of Chicago Press.

Heider, Karl. 1979. Grand Valley Dani: Peaceful Warriors. New York: Holt, Rinehart and Winston.

Holton, Gary - Hachibmai, Calistus - Haleyalur, Ali - Lipka, Jerry Rubinstein, Donald. 2015. East is Not a 'Big Bird': The Etymology of the Star Altair in the Carolinian Sidereal Compass. Oceanic Linguistics 54, 2: 579-588.

Hviding, Edvard. 1995. Maritime Travel, Present and Past, in Marovo, Western Solomon Islands. In: Feinberg, Richard (ed.): Seafaring in the Contemporary Pacific Islands: Studies in Continuity and Change. DeKalb, IL: Northern Illinois University Press: 90-113.

Lepowsky, Maria. 1995. Voyaging and Cultural Identity in the Louisisade Archipelago of Papua New Guinea. In: Feinberg, Richard (ed.): Seafaring in the Contemporary Pacific Islands: Studies in Continuity and Change. DeKalb, IL: Northern Illinois University Press: 34-54.

Lévi-Strauss, Claude. 1963a. The Bear and the Barber. Fournal of the Royal Anthropological Institute of Great Britain and Ireland 93, 1: 1-11.

Lévi-Strauss, Claude. 1963b. Structural Anthropology. Translated by Claire Jacobson and Brooke Grundfest Schoepf. New York - London: Basic Books.

Lévi-Strauss, Claude. 1963c. Totemism. Translated by Rodney Needham. Boston: Beacon Press. (Original: 1962)

Lévi-Strauss, Claude. 1966. The Savage Mind. Chicago: University of Chicago Press. (Original: 1962)

Lewis, David. 1972. We, the Navigators. Honolulu: University of Hawai' $\mathrm{i}$ Press.

Luomala, Katherine. 1949. Maui-of-a-thousand-tricks: His Oceanic and European Biographers. Honolulu: Bernice P. Bishop Museum.

Malinowski, Bronislaw. 1922. Argonauts of the Western Pacific. New York: E. P. Dutton.

Metcalf, Peter. 1976. Birds and Deities in Borneo. Bijdragen tot de TaalLand-en Volkenkunde 132, 1: 96-123.

Métraux, Alfred. 1940. Ethnology of Easter Island. Honolulu: Bernice P. Bishop Museum.

Montague, Susan P. 2001. The Trobriand Kinship Classification and Schneider's Cultural Relativism. In: Feinberg, Richard - Ottenheimer, 
Martin (eds.): The Cultural Analysis of Kinship: The Legacy of David M.

Schneider. Urbana, IL: University of Illinois Press: 168-186.

Outer Voices. n.d. Story of Lata: Solomon Islands, narrated by

Stephanie Guyer-Stevens: https://outervoices.org/the-story-of-lata/.

Richter-Gravier, Raphael. 2019. Manu Narratives of Polynesia:

A Comparative Study of Birds in 300 Traditional Polynesian Stories.

Ph.D. dissertation: University of Otago and the University of French Polynesia.

Steinbeck, John. 1937. Of Mice and Men. New York: Penguin. 